\title{
Impact of Family Ownership on Organizational Performance With the Moderating Role of Active Versus Passive Control: A Case of Pakistan's Private Sector
}

\author{
Dr. Muhammad Shaukat Malik \\ Director of Institute of Banking \& Finance, Bahauddin Zakariya University. Pakistan \\ E-mail: shoukatmalik@bzu.edu.pk
}

Mian Muhammad Tayyab,

Institute of Banking and Finance, Bahauddin Zakariya University. Pakistan

E-mail: mianmuhammadtayyab@gmail.com

Received: Jul. 11, 2019 Accepted: Aug. 19, 2019 Online published: Sep. 18, 2019

doi:10.5296/ijhrs.v9i4.15478 URL: https://doi.org/10.5296/ijhrs.v9i4.15478

\begin{abstract}
Most of the businesses operations in the world are governed typically by a family or a government and in some other situations, sole person regulates the operations of several firms beneath a single umbrella. The main purpose of the study is to examine the association between ownership structure of the business and its performance. The sample of the study is based on 100 companies listed in KSA (Karachi stock Exchange). The data was gathered from secondary sources of financial reports of firm and the time period is based on 9 years from 2005 to 2013. Financial performance of the firm is calculated through the accounting based methods like as several ratios of Return on asset, Net Profit Margin, Return on Equity, Financial Leverage, Tobin's Q and Earning per share. Several statistical tools (e,g Correlation, reliability, regression analysis and t-test) are used to measure the results on SPSS. Active and passive controls are used as moderator in the study. According to the result it is concluded that all hypothesis are accepted. Similarly, a significant difference is existed in firm performance under active and passive control. This study is very helpful for the investors and the business owners of family owned firms.
\end{abstract}

Keywords: family owned structure, return on asset, return on equity, financial leverage, net profit margin, earnings per share, Tobin Q, active control, passive control 


\section{Introduction}

\section{Background of the study}

In the corporate world different types of business structures exist, but very famous are family and non-family owned businesses. In family owned business the family owns and controls the business strategically, the non-family business is the business in which businesses is owned and controlled by some professional managers who have full expertise in their field. We can say that in non-family owned business the management of business is outsourced. Family owned business structure is one of the famous structure in the corporate world. In this regard lot of research (later and past) has been conducted by very famous financial researchers in which they are interested to find out the exact relationship between the firm performance and the ownership structure of the firm. And in their findings they found the diverse results (Ahmad et al., 2014).

So here it is important before discussing more in this regards, we must have a clear definition of family and non-family business. Although recent studies show that family owned businesses are much better in their operational activities compared to non-family owned business. Recently some empirical results of some authors are studied in which they argue the mixed results, which may be due to somewhat two sort of problems i.e. one is related to model specification and other is model estimation. Importantly researchers show that in many firms the family exists in the same firm with a long period of time, and holds significant portion of equity, and regulation of administration abode them in a status to influence and observe the firm(Anderson and Reeb, 2003; Villalonga and Amit, 2006, Miller et al, 2007).

\section{Significance of the study}

Although the research on the family and non-family business is extensively explored in worldwide, but very little work has been done in Pakistan, so at global research the researchers or financial scientists have developed different definitions of family and non-family business, but very concisely and comprehensively the family firm can be defined the firm as in which establishing members of the family hold the top position in the firm management, on the board, or the block holder of the company (Chen et al., 2007.). Alike description has been observed by other researchers Anderson and Reeb (2003) in which they say that a firm based on family ownership is a firm in which the originator supporter of the family are in management whichever for the blood relation and by marriage must hold the captain category in the firm i.e. director, or must be block holder. In 2007 another author introduced a very comprehensive definition in which he says that a company is called a family firm where " the founding members of the firms have controlling interest in the firm management" (Bennedsen, $\mathrm{M}$ et al, 2010). In the case of family firms the family objectives and aims are much carefully connected with the aims and objectives of the firm, and accordingly they are organized by a focused group of family associates (Hasan, M. S., Rahman, R. A., \& Hossain, S. Z, 2014). According the world wide best authors the family business is a ubiquitous such authors Shleifer and Vishny, 2002 Anderson and Reeb, (2003). 


\section{Objectives of the Study}

Following are the research objectives of this research study:

1) To observe the impact of family possession on firm operations and performance.

2) To inspect the moderator role of active versus passive family regulation on the association between family ownership structures with the financial performance of the firm.

3) To make recommendations and suggestions to the concerned organizations in the private sector of Pakistan on the basis of empirical evidences.

\section{Research Questions}

This study goes for looking at this relationship from three different points of view.

1. Are family firm less efficient or less important than non-family firm?

2. To analyze that if founding family possession influences on firm operations and financial performance is the association of performance and possession is lined over all collections of family assets.

3. Does the involvement level of family increase or decrease the performance of the firm? This inspection offers a study of these explorations, applying firm - level material from the private sector companies of Pakistan.

\section{Research Implications}

The research on the impact of family ownership business structure and control on the financial performance of the firm has gathered excessive interest all over the globe. The interest around the association among active \& passive control and possession structure and financial performance has appealed numerous researchers to effort in this area of study. The $1^{\text {st }}$ question that arose into mind is whether family owned firms are different in performance, on the basis of active and passive control. The query is essential to answer because if there is no variance or dissimilarity is existed then the research becomes impractical.

\section{Literature Review}

From the previous few decades the subject about ownership structure and financial performance of the firm has been discussed by the financial scientist and researcher. The very important and vital difficulties and benefits of possession structure of the businesses, in the direction of the performance of the business have been explored by the Jabeen, M., \& Shah, A. (2011), According to Gallo, M. A., \& Cappuyns, K, (2004) the family owned business are those in which, not just only the majority of shares are held privately but also they were active in operational and strategic management of the firm. Usually the family owned businesses take up firm aims that are not well-matched with the great objectives of the business, and simply they pick those strategies that are in fact low risk in nature for the sake to preserve the mechanism of possession to specific shareholders. In the study of different financial researchers such as, studies that public or non-family business have a broader 
horizons in access of long term greater credit, compensation package for management in term of stock offers, greater promotion of the firm and outsource monitoring of the firm. In public ownership structure organization could perhaps generate agency difficulties in administrative mechanism.

According to Amit (2006) as compared to the public ownership organization the organizations which are based on private or family ownership structure also have the best investment decision in the firm and the best utilization of investment in long time horizon. Actually these are the reasons from that they yield a more consistent and established and extended method towards the administration of the business. Nevertheless this can be remunerated with the charge of the isolated possession.

According to the study of Isakov, D., \&Weisskopf, J. P. (2009) a firm is managed and controlled by the family fellows may be considerably less talented and tolerates damages, as compared to the firm that is managed and controlled by the outsider or outsource management. The performance of the firm is very much important and crucial for both types of structures of the firm because only from this yard stick the outsider or insider stake holders make their investment decisions from the performance of the firm.

\subsection{Family Organizations and Non-Family Organizations Ownership Structure}

For the purpose to differentiate the family \& non-family firm, it is important to define both the terminologies of family and non-family business. In the literature review of family \& non-family ownership structure diverse writers have used diverse methods to calculate whether a particular firm is a family or non-family owned according to the requirements of their particular research. According to Dolz, C., Iborra, M., \&Safón, V. (2018)the businesses which have family owned structures are those companies in which the different family members are working together in the same firm with some different designations, so such type of firm will be called family firm. The members of family are functioning in the firms will be very much loyal and sincere with the firm always they save the interest of the firms as compared to other types of shareholder of the firm. Usually it has been seen that family firm' s bear lower debt financing cost. Kim, H., \& Han, S. H. (2018) describe that when a family make some key decision at horizon level or make a systematic corporate strategy, then we see that is a family firm. Only the family members make strategies, implement and control and play a vital in planning phase of the firm that means that all the process are in the hand of the members of the family. Martínez-Ferrero, et al, (2016) demonstrate in their studies that if in a firm $33 \%$ shares own by single family, we can say that such type firm is family business.

There are basically three types of categories are available that categorizing the family \& non-family organization. The $\mathbf{1}^{\text {st }}$ group is of pure nature of family ownership in which the family members are owned and control the firm' s overall operation from low level to top level so this type of firm is called family owned firm, in addition to that there is a sub category is available in which the managers of the firm are the family members of owner of the firm. And a second type is in which managers are outsourced for the management purpose and the overall firm is owned and controlled by a single family. And third category 
is that in which all the management of the firm is totally outside, and such type of firm is called non family business Zulfiqar, M., \& Fayyaz, M. A. (2014).

\subsection{Family Businesses in Pakistan}

The family ownership in Pakistani firms having the utmost importance, in this country majority of the manufacturing sector is owned and control by the different families. So here it would not be incorrect to express that family businesses are the mainstay of the economy of Pakistan. In Pakistan typically the private limited businesses are owned and control by the family businesses. Usually it has been observed that the shares are not easily transferable in private limited companies. In Pakistan also very large no of firms are public limited corporations and are family owned businesses. It is very much interesting to mention that in Pakistan the public limited businesses also have a large role of family firm.

\subsection{Influence of Family Possession on Firm Performance}

Family ownership has a few hypothetical points of interest. First, management of family firms settle on best investment choices due to the way that participants of the family have all firm particular information of the firm besides are in this way more farsighted.

Consistently with the above specified studies numerous empirical researches like as Palia and Zulfiqar, M., \& Fayyaz, M. A. (2014) have created optimistic effect of family possession on firm performance.

Though, the overhead benefits of family possession will be balanced by possible costs of family possession. In line with these prospects, Camisón, C., Forés, B., \& Puig-Denia, A. (2016) initiated in their research that the response of market was adverse when family firm employed family participants as directors in the company. For example, Villalonga and Amit (2006) compete that there is a likelihood of lesser shareholders' expropriation in family based firms. Observational outcomes related with the influence of family possession on firm performance are mixed. Barontini and Caprio (2004) inspected the outcomes of the association among firm performance and possession structure with the examination of 675 companies registered as public operated companies range out in 11different nations all through the mainland of Europe. Their outcomes presented that family control absolutely influenced the performance of the companies in Europe. Barontini and Caprio (2006) deliberate that the return on Assets \& Tobin Q of a firm that is based on family ownership were low.

\subsection{Influence of Non-Family Possession on Firm Performance}

From the investigation of literature review regarding the ownership structure of the firms the literature review reveals that family owned business is very much dissimilar from the non-family possessed business in numerous conducts e.g. series of regulation, investment, borrowing and financial policies etc. most of the research reveals that family firms propose more customer oriented services and participation, and have a special worry for the worker gratification, and have great respects of local traditions, customs of the locality and in addition to all that the family firms have more concern to give the best opportunities for 
women. But all of this family owned business face lot of problems. The problems regarding joint decision making, succession related issues and the supervision and management of the family member' s employee' s discipline etc. Chau, G., \& Gray, S. J. (2010). Although around the world the no. of minor and average sized companies are family companies, literature displays these companies are speedily developing and very popular companies. Some studies report that family businesses have the similar nature interests and face similar nature problem and hardship in all over the world Dolz, C., Iborra, M., \& Safón, V (2018).

\subsection{Moderating Effect of Control in Firm Performance}

The firm performance of the firm is achieved with different independent variables at their optimal level of affect in which we categorize.

In performance measurement of the firm in which we are including the dependent variable of the firm performance for measuring the firm performance there are two sort of measure are as under:
a. Market base performance
b. Accounting base performance, Anderson et al. (2003)

For market base performance of the firm we use the Tobin's Q, while for measuring the accounting performance we use two different tool one is return on Equity (ROE) and second is return on Assets(ROA). In this regard there are different sort of independent variables working in which one is ownership structure of the firm. So here we see that this relationship is moderate from both the control associated with the firm in which we can categories them as follows:

\section{a. Active control \\ b. Passive control}

Active control is in which the owner is directly involved in the board and management of the firm, and passive control means that top management of the firm is outsourced and the owner is outside from the working of the firms McCahery, J. A., \&Vermeulen, E. P. (2006).

So here in our study aim to find out the moderating effect of active and passive control over the firm performance. There is very clear difference exist of the performance of the firms that are controlled by actively or passively.

\section{Types of control while measuring firm performance}

\section{- Active control}

\section{- Passive Control}

\subsection{Impact on Financial Performance of the Firm}

Different authors adopt different measures for the calculation of firm performance, the Demsetz and Lehn used the accounting profit rate to measure the firm performance. And rest of the studies they use the Tobin' Q. 


\section{Macrothink \\ International Journal of Human Resource Studies \\ ISSN 2162-3058 \\ 2019, Vol. 9, No. 4}

2.6.1 Market Base Performance (i.e Tobin's Q)

James Tobin and Nobel laureate from Yale University studied that "The combined total market value of all the firm in the stock market should be equal to their replacement cost" . So hence the ratio can be written as follows:

Tobin's $\mathrm{Q}=$ total market value of the firm divide by total assets held by the firm

Where,

Total market value of the firm $=$ market value of the equity + liabilities or debt

Market value of equity $=$ No. of shares outstanding $\mathrm{x}$ market share price

Debt $=$ total asset - equity

A low response of Tobin's Q (0-1) bring up that a more prominent cost is suggested to supplant the firm' s advantages than the stock's value. Accordingly it demonstrates that the stock of the firm is underestimated in the market. Interestingly a higher answer of Tobin's Q advocates that the company's stock is more immoderate than the cost of firm' s benefits substitution.

\subsubsection{Return on Equity}

(ROE) Return on equity is essentially a quantity of net return that is reverted as a fraction of stockholders equity. Return on equity regulates the productivity of the business, by enlightening the detail that how much business produce a profit in contradiction of the investment of stockholders investment.

Return on equity is articulated as a proportion and control as shadows:

\section{Return on Equity = Net Income of the business /Stockholder's Equity capitalized in the business}

Net income is intended for complete fiscal year, Stockholder's equity does not comprise preferred stock.

\subsubsection{Return on Assets}

The concept Return on assets is based on an amount of net income that is produced by a specific company alongside the total assets capitalized in the company (total assets comprises stakeholders equity $+\mathrm{debt}$ ). The profit on assets is intended by the succeeding technique:

\section{Return on Asset $($ ROA $)=$ Net Income of the firm / Total assets of the firm}

This ratio provide a yard stick to confirm that how efficiently financial administrators utilize the investment of solo $\$$ in the asset of the firm, because of this reason that the sole $\$$ is approached from depositor or creditors (Gibson, 2001, analysis of financial statements) 


\section{Theoretical Model}

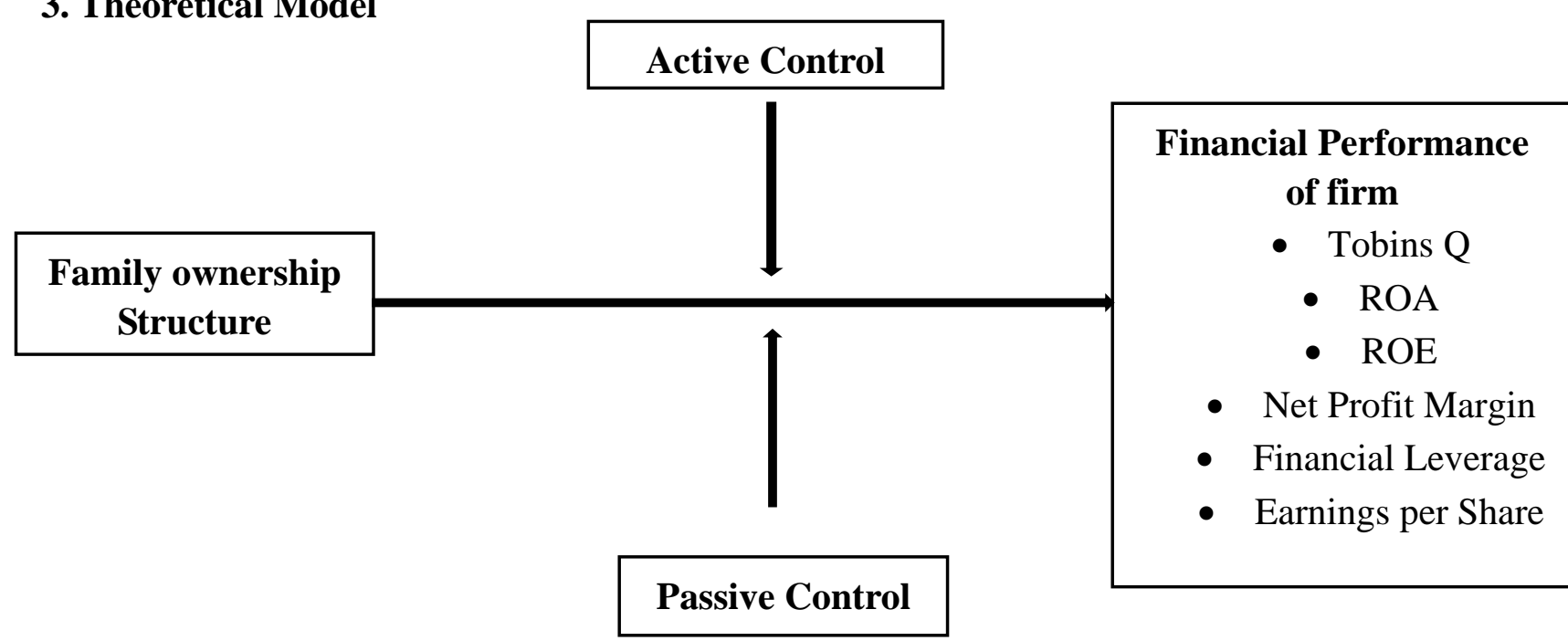

Figure 1.

\section{Mathematical Model}

$$
\begin{aligned}
\mathrm{TQ} & =\beta 0+\beta 1(\mathrm{FO})+\beta 2(\mathrm{FC})+\beta 3(\mathrm{FS})+\beta 4(\mathrm{FG})+\beta 5(\mathrm{FA})+\beta 6(\mathrm{MB})+\mu \mathrm{it} . \\
\mathrm{ROA} & =\beta 0+\beta 1(\mathrm{FO})+\beta 2(\mathrm{FC})+\beta 3(\mathrm{FS})+\beta 4(\mathrm{FG})+\beta 5(\mathrm{FA})+\beta 6(\mathrm{MB})+\mu \mathrm{it} . \\
\mathrm{ROE} \quad & =\beta 0+\beta 1(\mathrm{FO})+\beta 2(\mathrm{FC})+\beta 3(\mathrm{FS})+\beta 4(\mathrm{FG})+\beta 5(\mathrm{FA})+\beta 6(\mathrm{MB})+\mu \mathrm{it} . \\
\mathrm{FL} & =\beta 0+\beta 1(\mathrm{FO})+\beta 2(\mathrm{FC})+\beta 3(\mathrm{FS})+\beta 4(\mathrm{FG})+\beta 5(\mathrm{FA})+\beta 6(\mathrm{MB})+\mu \mathrm{it} . \\
\mathrm{NPM} \quad & \beta 0+\beta 1(\mathrm{FO})+\beta 2(\mathrm{FC})+\beta 3(\mathrm{FS})+\beta 4(\mathrm{FG})+\beta 5(\mathrm{FA})+\beta 6(\mathrm{MB})+\mu \mathrm{it} . \\
\mathrm{EPS} & =\beta 0+\beta 1(\mathrm{FO})+\beta 2(\mathrm{FC})+\beta 3(\mathrm{FS})+\beta 4(\mathrm{FG})+\beta 5(\mathrm{FA})+\beta 6(\mathrm{MB})+\mu \mathrm{it} .
\end{aligned}
$$

Whereas TQ is Tobin's Q, ROA is return on asset, ROE is return on equity, FL is financial leverage, NPM is net present value, EPS is earning per share, FO is firm ownership, FC is firm control, FG is firm growth, FA is firm age, and MB is market to book value of the firm.

\subsection{Hypothesis}

Based upon the framework, the following hypotheses are suggested:

H1 Family ownership structure has significant impact on financial performance of the firm.

H1a Family ownership structure significantly impacts Return on Asset (ROA) of private sector companies in Pakistan

H1b Family ownership structure significantly impacts Profit Margins of private sector companies in Pakistan

H1cFamily Ownership structure significantly impacts Financial Leverage of private sector companies in Pakistan

H1d Family ownership structure significantly impacts Return on Equity of private sector 
companies in Pakistan

H1eFamily ownership structure significantly impacts Earnings per Share of private sector companies in Pakistan

H1f Family ownership structure significantly impacts Tobin's Q of private sector companies in Pakistan.

H2 Active control has a significant moderating impact on the relationship of family owned businesses and financial performance of the firm.

H3 Passive control has a significant moderating impact on the relationship of family owned businesses and financial performance of the firm.

H4 There is significant difference in financial performance of the firm under Active and passive control.

\subsection{Measurement of Variables}

In the research domain of family firms and firm performance, there are different proxies used to determine the market base performance and accounting base performance of the firm. So in accounting base variables we include return on Assets, return on equity, Net profit Margin, whereas for the purpose of market base we include variables such as financial leverage, earning per share, and Tobin's $\mathrm{Q}$. The choice of these six variables is in consistence with the procedure of the calculations adopted by previous research scientist McCahery, J. A., $\&$ Vermeulen, E. P. (2006). The descriptions and demonstrations of the applicability of these variables are as follows:

\subsection{Measurement of Variables}

\begin{tabular}{|l|l|l|l|}
\hline Variable & Symbol & Measurement & Reference \\
\hline Firm Size & $F S$ & Natural log of total assets & $\begin{array}{l}\text { (Massis D et al, } \\
2013)\end{array}$ \\
\hline Firm Growth rate & $F G$ & $\begin{array}{l}\text { Geometric mean of annual percentage } \\
\text { increase in assets }\end{array}$ & $\begin{array}{l}\text { (Harold Demsetz, } \\
\text { Bele Villalonga } \\
2001)\end{array}$ \\
\hline $\begin{array}{l}\text { Market to Book } \\
\text { Value }\end{array}$ & RB & $\begin{array}{l}\text { Ratio of market value per share to } \\
\text { book value per share }\end{array}$ & $\begin{array}{l}\text { Leenders, M. A., } \\
\& \text { Waarts, } \\
(2001) .\end{array}$ \\
\hline Firm Age & $F A$ & $\begin{array}{l}\text { Difference between focal year and year } \\
\text { of incorporation }\end{array}$ & $\begin{array}{l}\text { Leenders, M. A., } \\
\& W a a r t s, ~ \\
(2001) .\end{array}$ \\
\hline Family ownership & $F O$ & $\begin{array}{l}\text { No. of percentage shares held by a a } \\
\text { family }\end{array}$ & $\begin{array}{l}\text { (Bekiris\&Doukakis, } \\
\text { 2011) }\end{array}$ \\
\hline Family control & $F C$ & $\begin{array}{l}\text { If family CEO exist (i.e active control) } \\
\text { we denote }=1, \text { otherwise (i.e passive }\end{array}$ & $\begin{array}{l}\text { (Carmen Galve et } \\
\text { al. 2011) }\end{array}$ \\
\hline
\end{tabular}




\begin{tabular}{|c|c|c|c|}
\hline & & control) we denote $=0$ & \\
\hline Tobin's Q & $Q$ & $\begin{array}{l}\text { (book value of debt }+ \text { market value of } \\
\text { equity) / book value of assets }\end{array}$ & $\begin{array}{ll}\text { Barontini } & \text { and } \\
\text { Caprio (2006) } & \\
\end{array}$ \\
\hline Return on Assets & $R O A$ & Net income / total assets & $\begin{array}{l}\text { Habbershon, T. G., } \\
\text { \& Williams, M. L. } \\
(1999)\end{array}$ \\
\hline Return on Equity & $R O E$ & $\begin{array}{l}\text { Net income / total Shareholder's } \\
\text { Equity }\end{array}$ & $\begin{array}{l}\text { Habbershon, T. G., } \\
\text { \& Williams, M. L. } \\
(1999)\end{array}$ \\
\hline Net profit Margin & $N P M$ & Net Profit/Total sales & $\begin{array}{l}\text { Fan, J. P., \& Wong, } \\
\text { T. J. (2002). }\end{array}$ \\
\hline $\begin{array}{ll}\text { Earnings } & \text { Per } \\
\text { Share } & \\
\end{array}$ & EPS & Net Profit/no. of shares outstanding & $\begin{array}{l}\text { Fan, J. P., \& Wong, } \\
\text { T. J. (2002). }\end{array}$ \\
\hline Financial leverage & $L E V$ & Total debts / total assets & $\begin{array}{l}\text { (Massis D et al, } \\
\text { 2013) }\end{array}$ \\
\hline
\end{tabular}

\section{Research Methodology}

As the terminology of this study method, is uneasy with measureable data Kamran, K., \& Shah, A. (2014). It has a numerous supported statistical standards for the rationality and consistency of this study method, such as, the number of participants that are mandatory to shape up a statistical significant outcome. In our research model we utilized the quantitative approach in our research analysis. We use the financial and accounting base data from the annual financial reports of 100 listed companies is PSX. This approach is best in this regards because we know that this approach holds the various acknowledged statistical tools and techniques.

According to the requirement of this study, quantitative method is the best approach to calculate the results for this purpose; statistical quantitative techniques are used with the help of SPSS software to calculate the findings of the study. In this study longitudinal data collection technique is utilized this approach and collect the data of 9 years i.e. from 2005 to 2009 from the annual financial reports of 100 listed companies in Pakistan stock exchange.

\subsection{Sample Size}

The size of the sample resembles to the amount of participants selected from the overall population that are applied as a fragment of the study. In the study analysis based on quantitative analysis, the degree of the sample is spirited in determining the consistency of the outcomes of a research.

Usually it can be said that, the larger the sample quantify the better will be the results (Gallo, M. A., \& Cappuyns, K. (2004). 
Table 4.1.

\begin{tabular}{|l|l|l|}
\hline $\begin{array}{l}\text { Details of firms included in a sample on the } \\
\text { basis of Active and passive family control }\end{array}$ & $\begin{array}{l}\text { Active family } \\
\text { control }\end{array}$ & $\begin{array}{l}\text { Passive } \\
\text { control }\end{array}$ \\
\hline Initial Sample & 125 & 110 \\
\hline Non-Operating & 23 & 13 \\
\hline Missing Financial Data or negative values & 52 & 47 \\
\hline Final Sample & 50 & 50 \\
\hline
\end{tabular}

Primarily we remove the firms like as banks, monetary companies, from our sample. Equally, the non-operational through the study declared period, or those organizations that are possessed and organized by other corporations functioning in diverse countries, were omitted in our study sample. We also omitted those organizations that have the adverse equities, and those with data inaccessible in the duration of this research. Thus, in our final we are with 100 companies which are based on actively and passively family controlled.

\subsection{Data Collection and Analysis}

One of our primary concerns is the identification of family firms. As prior research provides only limited guidance on how to ascertain family firms, we use the fractional equity ownership of the founding family and (or) the presence of family members on the board of directors to identify family firms.

Research analysis and data gathering are vital part of every research approaches. (Ehrhardt, O., Nowak, E., \& Weber, F. M. (2006). The process applied at this stage of the research analysis donates fundamentally to the research's over-all reliability and strength. Nevertheless the approach applied as a part of the scheme, the type of data gathering can be remote into two kinds: primary \& secondary. In this research only secondary data is used to calculate the results and software SPSS is used to run regression analysis on given data.

\section{Data Analysis and Techniques}

The key emphasis of this research was to define Impact of Family Ownership on Organizational Performance with the Moderating Role of Active Versus Passive Control: A Case of Pakistan' s Private Sector and to assess a theoretical model on the basis of three main hypothesis developed in the study. The statistical results of this research are shown in tables. All statistical analysis was done on SPSS software which is used for time series analysis.

\section{Regression model specifications:}

The model of the linear regression was the first type of regression analysis, which has been studied and analysed extensively in the practical applications. The linear regression is a methodology for developing the exact relationship between the dependent variable, usually we denote as $\mathrm{Y}$, more than one explanatory variables or we can say the independent variables usually we denote as $\mathrm{X}$. if in research analysis only one explanatory variable is used against 
the dependent variable, than such type of regression is called simple linear regression. And if for more than one explanatory variables are involved in research analysis, the process is called multiple linear regression. Here it is important to mention that this term should be distinguished from the multivariate linear regression, where more than one correlated dependent variable are predicted rather than a single explanatory variables. In our research project we employ the multiple linear regression where we have the family ownership (FO) as an explanatory variable and other independent variables we are using the family control (FC), firm growth (FG), firm age (FA), and market to book value (MB). So here in our regression model we use two types of moderators one is active family control and other is passive family control. The firm performance we are using in terms of market base and accounting base, where for the measuring the market base performance we use Tobin' $s$, and for accounting base performance we use different tools like ROA is return on asset, ROE is return on equity, FL is financial leverage, NPM is net present value, EPS is earning per share.

\subsection{Descriptive Statistics}

According to descriptive analysis, Minimum, Maximum, Mean, and Standard Deviation are mentioned. Family ownership has minimum of 1.25 and maximum of 5. According to the other values, the same is the case and the standard deviation is maximum in the values of firm performance. So the standard deviation is the change in minimum to maximum values.

\section{Descriptive Statistics for Dependent and Independent Variables}

Table 5.1. Descriptive Statistics

\begin{tabular}{|l|l|l|l|l|l|l|}
\hline & N & Minimum & Maximum & Mean & $\begin{array}{l}\text { Std. } \\
\text { Deviation }\end{array}$ & Variance \\
\hline $\begin{array}{l}\text { Financial } \\
\text { Performance }\end{array}$ & 900 & -105.24 & 198.88 & 7.2054 & 19.43842 & 377.852 \\
\hline $\begin{array}{l}\text { Family Ownership } \\
\text { in \% }\end{array}$ & 894 & 23.28 & 92.11 & 58.5975 & 15.81724 & 250.185 \\
\hline
\end{tabular}

Descriptive shows that the mean of the financial performance is 7.20 while the S.D is 19.43842. While for family ownership there are $58.59 \%$ on average owner with S.D 15.81724 .

\subsection{Normality Test}

Shapiro-Walk test of normality

\begin{tabular}{|l|l|l|l|l|l|}
\hline Variable & Obs & W & V & Z & p-value \\
\hline TobinsQ & 898 & 0.74167 & 147.725 & 12.316 & .000 \\
\hline ReturnonEq y & 900 & 0.04866 & 545.118 & 15.536 & .000 \\
\hline ReturnonAs $\sim \mathrm{t}$ & 900 & 0.63014 & 211.929 & 13.207 & .000 \\
\hline
\end{tabular}




\begin{tabular}{|l|l|l|l|l|l|}
\hline NetProfitM $\sim \mathrm{n}$ & 891 & 0.07472 & 525.363 & 15.439 & .000 \\
\hline FinancialL $\sim \mathrm{e}$ & 900 & 0.77633 & 128.165 & 11.967 & .000 \\
\hline EarningPer $\sim \mathrm{e}$ & 900 & 0.75328 & 141.369 & 12.209 & .000 \\
\hline FamilyOwne n & 894 & 0.98208 & 10.204 & 5.726 & .000 \\
\hline
\end{tabular}

This analysis is actually done to see the normality in the given data, either it is capable of applying statistical tools or not. The data is in normal condition if the p value is less than 0.05 . Therefore from the above table it is clear that the available data is normal because all the results come under range of $\mathrm{p}$ value.

\subsection{Summary Table of Regression Analysis}

\begin{tabular}{|c|c|c|c|c|c|c|}
\hline \\
\hline \multicolumn{2}{|l|}{ Models } & \multirow{2}{*}{$\begin{array}{l}\text { R square } \\
\\
.007\end{array}$} & \multirow{2}{*}{$\begin{array}{r}\mathrm{F} \\
5.342\end{array}$} & \multirow{2}{*}{$\begin{array}{r}\text { Sig } \\
.000\end{array}$} & \multirow{2}{*}{$\begin{array}{r}\text { Beta } \\
.264\end{array}$} & \multirow{2}{*}{$\begin{array}{r}\mathrm{Sig} \\
.000\end{array}$} \\
\hline $\begin{array}{l}\text { Model } 1 \\
\text { Financial } \\
\text { Performance } \\
\text { of the firm }\end{array}$ & $\begin{array}{l}\text { Family } \\
\text { ownership } \\
\text { structure }\end{array}$ & & & & & \\
\hline $\begin{array}{l}\text { Model } 2 \\
\text { (Moderation } \\
\text { Effect) } \\
\text { M_IV }\end{array}$ & $\begin{array}{l}\text { M1_FO } \\
\text { M2_FO }\end{array}$ & $\begin{array}{l}.009 \\
.052\end{array}$ & $\begin{array}{l}5.432 \\
31.907\end{array}$ & $\begin{array}{l}.011 \\
.000\end{array}$ & $\begin{array}{l}.104 \\
.086\end{array}$ & $\begin{array}{l}.000 \\
.000\end{array}$ \\
\hline $\begin{array}{l}\text { Model } 3 \\
\text { Financial } \\
\text { Performance } \\
\text { of the firm } \\
\text { (ROA) }\end{array}$ & $\begin{array}{l}\text { Family } \\
\text { ownership } \\
\text { structure }\end{array}$ & .017 & 15.765 & .000 & .003 & .000 \\
\hline $\begin{array}{l}\text { Model } 4 \\
\text { Financial } \\
\text { Performance } \\
\text { of the firm } \\
(\mathrm{PM})\end{array}$ & $\begin{array}{l}\text { Family } \\
\text { ownership } \\
\text { structure }\end{array}$ & .000 & 17.96 & .000 & .014 & .032 \\
\hline $\begin{array}{l}\text { Model } 5 \\
\text { Financial } \\
\text { Performance } \\
\text { of the firm } \\
\text { (FL) }\end{array}$ & $\begin{array}{l}\text { Family } \\
\text { ownership } \\
\text { structure }\end{array}$ & .009 & 7.717 & .006 & .093 & .000 \\
\hline $\begin{array}{l}\text { Model } 6 \\
\text { Financial } \\
\text { Performance } \\
\text { of the firm } \\
\text { (ROE) }\end{array}$ & $\begin{array}{l}\text { Family } \\
\text { ownership } \\
\text { structure }\end{array}$ & .000 & 4.67 & .005 & .022 & .015 \\
\hline
\end{tabular}




\begin{tabular}{|l|l|l|l|l|l|l|}
\hline $\begin{array}{l}\text { Model 7 } \\
\text { Financial } \\
\text { Performance } \\
\text { of the firm } \\
\text { (EPS) }\end{array}$ & $\begin{array}{l}\text { Family } \\
\text { ownership } \\
\text { structure }\end{array}$ & .012 & 11.124 & .001 & .111 & .001 \\
\hline $\begin{array}{l}\text { Model 7 } \\
\text { Financial } \\
\text { Performance } \\
\text { of the firm } \\
\text { (Tobins Q) }\end{array}$ & $\begin{array}{l}\text { Family } \\
\text { ownership } \\
\text { structure }\end{array}$ & .001 & 1.316 & .012 & .038 & .020 \\
\hline
\end{tabular}

\subsection{T Test}

The $t$ test shows that the requirement of justification in moderating effect of Passive and Active control on family ownership structure is valid, because the significant value is .000 which is less than .05. It also shows there is substantial difference of mean in both divisions of control type. The mean difference of family ownership structure between active and passive control 3.3914, for Active control the 10.8699 for passive control.

Therefore, overall result show that $\mathrm{H} 4$ is approved and there is different impact verified by the results of t-test

\begin{tabular}{|c|c|c|c|c|c|c|}
\hline & Control & $\mathrm{N}$ & Mean & Std. Deviation & $\mathrm{t}$ test & p-value \\
\hline Family ownership & Passive & 441 & 3.3914 & 20.18551 & \multirow{2}{*}{-5.876324} & \multirow{2}{*}{0.0000} \\
\hline Structure & Active & 459 & 10.8699 & 17.96591 & & \\
\hline
\end{tabular}

\section{Conclusion and Major Findings}

The study delivers useful conclusions according to the aims of the researcher. One of the targets of this study was to inspect a possible association among active and passive control and their impact as moderator on the relationship of family owned business structure and financial performance of the firm., inside this framework of investigation, the research led to three main hypothesis. Acceptance and rejection of this hypothesis is based on the results of quantitative analysis through SPSS software.

H1 Family ownership structure has significant impact on financial performance of the firm.

The complete outcomes of Regression Analysis is significant and support first hypothesis, that there is significant relationship existed among family ownership structure and financial performance of the firm.

H1a Family ownership structure significantly impacts Return on Asset (ROA) of private sector companies in Pakistan.

Regression analysis is also done to check the separate relationship of family ownership structure and first dimension Return on Asset of financial performance of firm. The result shows the significant value. Therefore the hypothesis H1a is accepted.

H1b Family ownership structure significantly impacts Profit Margins of private sector 
companies in Pakistan

Regression analysis is also done to check the separate relationship of family ownership structure and second dimension profit margin of financial performance of firm. The result show the significant value. Therefore the hypothesis $\mathrm{H} 1 \mathrm{~b}$ is accepted.

H1c Family Ownership structure significantly impacts Financial Leverage of private sector companies in Pakistan.

Regression analysis is also done to check the separate relationship of family ownership structure and third dimension financial leverage of financial performance of firm. The result show the significant value. Therefore the hypothesis H1c is accepted.

H1d Family ownership structure significantly impacts Return on equity of private sector companies in Pakistan.

Regression analysis is also done to check the separate relationship of family ownership structure and forth dimension Return on equity of financial performance of firm. The result show the significant value. Therefore the hypothesis H1d is accepted.

H1e Family ownership structure significantly impacts Earnings per Share of private sector companies in Pakistan.

Regression analysis is also done to check the separate relationship of family ownership structure and fifth dimension Earnings per share of financial performance of firm. The result show the significant value. Therefore the hypothesis H1e is accepted.

H1f Family ownership structure significantly impacts Tobin's Q of private sector companies in Pakistan.

Regression analysis is also done to check the separate relationship of family ownership structure and sixth dimension Tobin' s Q of financial performance of firm. The result show the significant value. Therefore the hypothesis H1e is accepted.

H2 Active control has a significant moderating impact on the relationship of family owned businesses and financial performance of the firm.

This hypothesis is accepted as the both conditions of moderator is fulfilled according to the results. 1. The p-value is significant 2. Value of R-square increased from first regression model to second regression model. So, active control has a moderating impact on the relationship of family owned business structure and financial performance of the firm.

H3 Passive control has a significant moderating impact on the relationship of family owned businesses and financial performance of the firm.

The third hypothesis is also accepted as the both conditions of moderator is also fulfilled according to the findings of regression analysis. 1. The p-value is significant 2. Value of R-square increased from first regression model to second regression model. So, passive control has a moderating impact on the relationship of family owned business structure and financial performance of the firm. 
H4 there is significant difference existed among financial performance of the firm due to active and passive control

The result of $t$ test prove this hypothesis and its value express that there is substantial difference existed among financial performance of firm under active and passive control.

After analyzing all the results, it is clear that presence of active and passive control put a significant impact on relationship of family ownership structure and firm financial performance, which means when CEO is from the family members it effect the financial position and if CEO is not from family members and externally hired, it also put influence on the financial position of the firm. So, active and passive controls are very important in vase of family owned businesses. People CEO from their family mostly are more careful about their businesses but several times outer family CEO' s also perform very good. In Pakistan there are several examples of successful family owned businesses with active control especially in textile sector of Pakistan.

Overall, the findings ascertained that there is strong relationship exists among family owned structure and financial performance of the firm as All hypothesis related to each dimension of financial performance of firm are accepted.

\subsection{Recommendations}

As family owned businesses (FOBs) show more better financial position under active control situation. So, companies should consider this case while hiring the CEO of the firm. It is recommended for depositors to rank their investments in family business relatively. It is suggested to regularity authority of (KSE) to take steps that implement the businesses to act on special policies for family owned business.

In Pakistan typically companies have family possession structure and there is very slight research accessible on family and non-family possession structure of businesses in Pakistan. Family possession firms play a vital role in economy of the Pakistan. So for the further studies have more space in Pakistan.

Investors should take decisions of future investments in family owned businesses because of greater percentage of net earnings as dividend payment. It is recommended to family firms that they should avoid external financing. On the other hand The Security Exchange Commission of Pakistan (SECP) - monotony authority was demanded to observe the firms about constancy in their dividend policy.

\subsection{Managerial Implication}

The results of present study indicate that family ownership influences surely on firm value, perhaps because of the possible welfares related to family owners, for example their long-term prospects and their concern to their position and status. These features along with an improved knowledge about the firm are likely to encourage family owners to invest subsequent worth enlargement rules. However, a more precise analysis discloses that when family ownership attention is too great, the value of the firm starts decreasing. This decrease may because of possibility of expropriation of smaller stockholders by the owner family 
when it owns a great portion of the firm. In this situation, the present study delivers evidence that ownership attention has a powerful influence on firm value when it is in the fingers of a separate family. This outcome is reliable with the above-mentioned potential welfares related to family ownership. Moreover, we display that the powerful influence of ownership attention in the hands of a family grips after monitoring for nonlinearities. Generally, our outcomes specify that family firms performs outclass that it may be valuable to smaller shareholders. So, overall these results provide valuable information to its readers and also the owners of those specific companies which are the target sample of this study.

\subsection{Limitation of the Research}

Throughout the time of this thesis numerous ideas \& potential investigation areas have overlapped our minds. The aim of this segment is to serve as a foundation of motivation for advance researchers who want to do research relevant to this area of work.

To carry out the more examination allied to this topic, in this investigation the researcher used only measureable practices alone to explore the data; this was selected as it is suitable for the goals and purposes of the research. So, further studies should consider both techniques qualitative and quantitative. Sample of the study is also small, further research can be done on more firms under KSE and this study taken financial performance as independent variable other studies should be done with organizational performance that can be measured with primary data analysis, although this study is only based on secondary data analysis.

\section{References}

Abdullah, F., Shah, A., Gohar, R., \& Iqbal, A. M. (2011). The effect of group and family ownership on firm performance: Empirical evidence from Pakistan.

Ahmad, N., Nadeem, M., Ahmad, R., \&Hamad, N. (2014). Impact of Family Ownership on Firm's Financial Performance: A Comparison Study between Manufacturing Firms and Financial Firms in Pakistan. Nigerian Chapter of Arabian Journal of Business and Management Review, 2(8), 51-56. https://doi.org/10.12816/0011615

Anderson, R. C., \&Reeb, D. M. (2003). Founding-family ownership and firm performance: evidence from the S\&P 500. The journal of finance, 58(3), 1301-1328. https://doi.org/10.1111/1540-6261.00567

Andersson, J., Nordwall, J., \&Salomonsson, D. (2005). The link between ownership structure and firm performance Evidence from Sweden's listed companies.

Barontini, R., \& Caprio, L. (2006). The effect of family control on firm value and performance: Evidence from continental Europe. European Financial Management, 12(5), 689-723. https://doi.org/10.1111/j.1468-036X.2006.00273.x

Barontini, R., \&Caprio, L. (2004, September). The effect of ownership structure and family control on firm value and performance: Evidence from Continental Europe. In EFM, Symposium on" EuropeanCorporateGovernance" Leeds, UK, April2004, www. efmafm. org/OEFMSYMPOSIUM/sympo2005_papers. shtml. https://doi.org/10.2139/ssrn.675983 
Bennedsen, M., Pérez-González, F., \&Wolfenzon, D. (2010). The governance of family firms. Corporate governance: A synthesis of theory, research, and practice, 8. https://doi.org/10.1002/9781118258439.ch19

Camisón, C., Forés, B., \&Puig-Denia, A. (2016). Return on capital in Spanish tourism businesses: A comparative analysis of family vs non-family businesses. European journal of management and business economics, 25(3), 91-110. https://doi.org/10.1016/j.redeen.2016.04.002

Chau, G., \& Gray, S. J. (2010). Family ownership, board independence and voluntary disclosure: Evidence from Hong Kong. Journal of International Accounting, Auditing and Taxation, 19(2), 93-109. https://doi.org/10.1016/j.intaccaudtax.2010.07.002

De Massis, A., Kotlar, J., Campopiano, G., \& Cassia, L. (2013). Dispersion of family ownership and the performance of small-to-medium size private family firms. Journal of Family Business Strategy, 4(3), 166-175. https://doi.org/10.1016/j.jfbs.2013.05.001

Demsetz, H., \&Villalonga, B. (2001). Ownership structure and corporate performance. Journal of corporate finance, 7(3), 209-233. https://doi.org/10.1016/S0929-1199(01)00020-7

Dolz, C., Iborra, M., \&Safón, V. (2018). Improving the likelihood of SME survival during financial and economic crises: The importance of TMTs and family ownership for ambidexterity. BRQ Business Research Quarterly. https://doi.org/10.1016/j.brq.2018.09.004

Ehrhardt, O., Nowak, E., \& Weber, F. M. (2006). Running in the family the evolution of ownership, control, and performance in German family-owned firms 1903-2003. Swiss Finance Institute Research Paper, (06-13).

Fan, J. P., \& Wong, T. J. (2002). Corporate ownership structure and the informativeness of accounting earnings in East Asia. Journal of accounting and economics, 33(3), 401-425. https://doi.org/10.1016/S0165-4101(02)00047-2

Gallo, M. A., \&Cappuyns, K. (2004). Characteristics of successful family businesses. https://doi.org/10.2139/ssrn.683801

Habbershon, T. G., \& Williams, M. L. (1999). A resource-based framework for assessing the strategic advlantages of family firms. Family business review, 12(1), 1-25. https://doi.org/10.1111/j.1741-6248.1999.00001.x

Hasan, M. S., Rahman, R. A., \& Hossain, S. Z. (2014). Monitoring family performance: family ownership and corporate governance structure in Bangladesh. Procedia-Social and Behavioral Sciences, 145, 103-109. https://doi.org/10.1016/j.sbspro.2014.06.016

Isakov, D., \&Weisskopf, J. P. (2009). Family ownership, multiple blockholders and firm performance. In Finance International Meeting AFFI-EUROFIDAI. https://doi.org/10.2139/ssrn.1484574

Jabeen, M., \& Shah, A. (2011). A review on family ownership and information asymmetry.

Kamran, K., \& Shah, A. (2014). The impact of corporate governance and ownership structure 


\section{Macrothink}

International Journal of Human Resource Studies

ISSN 2162-3058 2019, Vol. 9, No. 4

on earnings management practices: Evidence from Listed Companies in Pakistan.

Kim, H., \& Han, S. H. (2018). Compensation structure of family business groups. Pacific-Basin Finance Journal, 51, 376-391. https://doi.org/10.1016/j.pacfin.2018.09.002

Leenders, M. A., \&Waarts, E. (2001). Competitiveness of family businesses: Distinguishing family orientation and business orientation. Marketing, 1000, 31.

Martínez-Ferrero, J., Rodríguez-Ariza, L., \&García-Sánchez, I. M. (2016). Corporate social responsibility as an entrenchment strategy, with a focus on the implications of family ownership. Journal of Cleaner Production, 135, 760-770. https://doi.org/10.1016/j.jclepro.2016.06.133

McCahery, J. A., \&Vermeulen, E. P. (2006). Corporate Governance and Innovation-Venture Capital, Joint Ventures, and Family Businesses. https://doi.org/10.2139/ssrn.894785

Villalonga, B., \& Amit, R. (2006). How do family ownership, control and management affect firm value?. Journal of financial Economics, 80(2), 385-417. https://doi.org/10.1016/j.jfineco.2004.12.005

Zulfiqar, M., \&Fayyaz, M. A. (2014). A Review of Family Ownership and Non-Family Ownership Firms' Performance, Productivity, and Profitability. Studies, 3(4).

\section{Copyright Disclaimer}

Copyright for this article is retained by the author(s), with first publication rights granted to the journal.

This is an open-access article distributed under the terms and conditions of the Creative Commons Attribution license (http://creativecommons.org/licenses/by/4.0/). 